Témoigner Témoigner. Entre histoire et mémoire

Getuigen Revue pluridisciplinaire de la Fondation Auschwitz

$121 \mid 2015$

Violences radicales en scène

\title{
Lavinia Stan. Transitional Justice in Post- Communist Romania: The Politics of Memory
}

Cambridge University Press, 2013

\section{Alina Thiemann}

\section{(Q) OpenEdition}

\section{Journals}

Electronic version

URL: https://journals.openedition.org/temoigner/3739

DOI: $10.4000 /$ temoigner.3739

ISSN: 2506-6390

Publisher:

Éditions du Centre d'études et de documentation Mémoire d'Auschwitz, Éditions Kimé

Printed version

Date of publication: 1 October 2015

Number of pages: $213-215$

ISSN: 2037-4183

\section{Electronic reference}

Alina Thiemann, "Lavinia Stan. Transitional Justice in Post-Communist Romania: The Politics of Memory", Témoigner. Entre histoire et mémoire [Online], 121 | 2015, Online since 01 October 2016 connection on 03 February 2022. URL: http://journals.openedition.org/temoigner/3739 ; DOI: https:// doi.org/10.4000/temoigner.3739

This text was automatically generated on 3 February 2022.

Tous droits réservés 


\title{
Lavinia Stan. Transitional Justice in Post-Communist Romania: The Politics of Memory
}

Cambridge University Press, 2013

\author{
Alina Thiemann
}

\section{REFERENCES}

Lavinia Stan, Transitional Justice in Post-Communist Romania: The Politics of Memory, Cambridge: Cambridge University Press, 2013, 288 p.

1 Scholarly work on transitional justice has typically focused on particular strategies to address past human rights abuses (e.g. truth commissions, memorialization, lustration), and only recently shifted toward more inclusive accounts. The book of political scientist Lavinia Stan, Transitional Justice in Post-Communist Romania: The Politics of Memory, contributes to this academic shift, synthetizing in a concise and coherent manner the complex processes of reckoning with the communist past in Romania during the first two decades of post-communism. Wisely navigating through the myriad of programs and initiatives adopted to push forward transitional justice, Stan uses the Romanian case to address two sets of questions currently debated by scholars in the field: on the one hand, to which extent time and sequencing of the transitional justice projects matter, and on the other hand, whether transitional justice fosters democracy.

While Romania has been understudied by scholars in transitional justice, Stan claims that this country deserves more academic attention due to the multitude of truth and justice projects in which it engaged and which can further serve as lessons in transitional justice. For instance, Romania was the only country in Eastern Europe to have a citizens' opinion tribunal and the first post-communist state to include in school curricula alternative history textbooks solely focusing on the communist times. 
Romania was also the first country to officially condemn Communism based on a lengthy report compiled by a historical commission and distinguished itself with respect to court trials. For instance, more than 4400 investigations were opened in Romania until 2004, although, as Stan notes, many of them dealt with the 1989 bloody Romanian Revolution rather than the communist human rights abuses. Stan claims that the Romanian Revolution was a topic of more interest than the communist past for both political actors and the general public, especially because it was closer in time than the atrocious crimes committed by communists during the first decades after WWII. Moreover, the fact that more than 1000 people died and more than 3000 were wounded in December 1989 seemed to eclipse the human rights abuses under Ceausescu's regime. Although the number of surviving political prisoners in 1990 exceeded the number of victims of the Revolution, the participants in regime's change in December 1989 were more vocal than the victims of Communism in requesting truth and justice for the bloodshed.

3 Understanding transitional justice as "the set of judicial and non judicial measures implemented by civil society actors, local and national governments and international organizations in view of redressing the legacy of massive human rights abuses" (17), the author identifies different mechanisms to address and correct the communist injustice, some of which are mainly specific to Eastern Europe (e.g. access to files compiled by secret police, lustration), while others were implemented in different regions in the world (e.g. court trials, historical and truth commissions, rehabilitation and compensation, citizens' opinion tribunals). All these justice programs are discussed in detail in thematic chapters, which mainly deal with state-led strategies to reckon with the communist violations of human rights. Although the author constantly emphasizes the role of civil society in putting pressure on the political elites to adopt policies to redress the communist injustices, as well as strategies to foster elite renewal (access to secret files, lustration), only one chapter is dedicated to unofficial memory or justice projects. Stan defines them as alternative mechanisms initiated and implemented by non-state actors, who have tried to substitute state institutions reluctant to investigate the communist regime. A distinction is made between memorialization projects, citizens' opinion tribunals, forensic investigations, secret information leaks ("vigilante justice"), and art and movie projects.

While the Romanian case might impress through the multitude of transitional justice measures, Stan reminds the reader that quantity does not necessarily translate into quality: "most programs implemented in Romania have scored low in terms of efficiency and efficacy" (233). Romania remained a laggard in Eastern Europe in implementing key transitional justice programs such as lustration, restitution of property, rehabilitation and compensation. One explanation offered and reinforced throughout the book refers to elite reproduction rather than elite renewal, which characterized post-communist Romania. Former members of the communist nomenclature remained in power and gained legitimacy by making a scapegoat of Ceausescu and advancing a "forgive-and-forget" strategy to deal with the communist past. According to Stan, this did not bring reconciliation but rather increased social divides in society given that former victims, as well as other social categories (e.g. students, members and supporters of the revived historical parties which were decimated by the communists) were not willing to accept it. The first post-communist elite comprising second-rank members of the Communist Party had no interest in a generic Trial of Communism, given that such a program would have challenged their 
position of power by holding them responsible for supporting and benefitting from the former regime. Therefore, they either delayed or blocked transitional justice measures: "The elite reproduction that followed the Stalinist dictatorship of Ceausescu and the bloody revolution of 1989 represented the most significant stumbling block the postcommunist transitional justice had to overcome." (234)

Not even when the political elite changed in 1996, with the electoral success of the Democratic Convention, did the rulers manifest any interest to reverse the situation until it became clear that they would lose the 2000 elections. This explains why several transitional justice projects were initiated in the late 1990s. The return to power of the Social Democrats meant a stagnation of truth and justice programs until the electoral campaign in 2004, which opened a "window of opportunity" for transitional justice in Romania. For several years, many significant programs were initiated and implemented by both state and non-state actors, such as the creation of a historical commission, the official condemnation of Communism, the occurrence of a citizens' opinion tribunal, the rehabilitation of political prisoners, and the introduction of alternative historical textbooks about the communist regime in the school curricula. Stan claims that President Traian Basescu agreed to follow the requests of the civil society for truth and justice only because these strategies brought him political capital and legitimacy at a particular moment in time. and order of truth and justice measures, and the relation between transitional justice and democracy. On the one hand, she revisits literature about timing and sequencing of transitional justice programs to show that in spite of the agreement that these two attributes matter, it is not clear how exactly they matter. The Romanian case indicates first that some measures open the path for others (e.g. rehabilitation of political prisoners was followed by meaningful compensation, the analysis of the communist dictatorship allowed for the official condemnation of communism). Second, the failure of some strategies to reckon with the communist past led to the development and implementation of other measures: the citizens' opinion tribunal was a response to the inability of the courts to initiate a Trial of Communism, and the leaks regarding the identity of former Securitate agents were caused by the failure of the National Council for the Study of Securitate Archives to disclose information regarding the Securitate collaborators and agents in a timely and trustworthy manner. Therefore, the unwillingness of the political elites to address the abuses committed under Communism could explain why Romania engaged in so many initiatives of transitional justice, although with less significant effects than in other countries. Third, the choice for particular programs of truth and justice blocked the implementation of other mechanisms. For instance, Stan suggests that the presidential appointment of a historical commission was preferred to a lustration with job losses, which could affect even the president in function.

7 On the other hand, Stan contests the assumption, shared by many scholars, that transitional justice fosters democracy by strengthening the rule of law and by elite renewal which can further restore the public trust in state institutions. There are indeed no studies to show a clear causal relation. Different contradictory examples where the same measure leads to different outcomes show that, as Stan notes, "transitional justice does not always precede, and explain, successful democratization" (249). This also applies in the Romanian case. Direct causal links 
between transitional justice programs and democracy in Romania can only be established if one ignores the impact of other local, national and international factors on democracy. Moreover, Stan provides examples which contradict this scenario, especially when actors in power disregard the rule of law and show arbitrariness and preferential treatment of different categories of citizens. While it is evident that the impact of never implemented programs cannot be assessed, Stan argues however that, in their absence, it becomes more likely that undemocratic strategies are used to maintain political power. For instance, she claims that the lack of lustration with job loss in Romania led to wild executive purges when political parties or coalitions tried to replace the administrative staff with people supporting the governing political formations. But this argument can be challenged. Indeed, it is not clear whether the implementation of a lustration program could have prevented the executive purges, which were perhaps caused by other factors.

Overall, the book makes an important contribution to the field of transitional justice by providing an in-depth analysis of all state-led programs that reckon with a former repressive regime. It explains in a rigorous manner the political and social struggles which influenced the adoption of specific legislation correct the crimes and abuses of communist dictatorship in Romania, a post-communist country characterized by elite reproduction rather than elite renewal. 